\title{
Dwifungsi tuturan oposisi dalam masyarakat bersosiokultur Jawa
}

\section{Fauzan}

Pendidikan Bahasa Indonesia, Fakultas Keguruan dan Ilmu Pendidikan, Universitas Muhammadiyah Malang, Jalan Raya Tlogomas Nomor 246, Malang, Jawa Timur, Indonesia

fauzan@umm.ac.id

*Corresponding author: fauzan@umm.ac.id

\begin{tabular}{l}
\hline Sejarah Artikel Diterima: 23 Februari 202I Direvisi: I9 April 202I \\
ABSTRAK \\
\hline \hline Kemunculan tindak tutur oposisi dalam wacana rembuk desa tidak terhindarkan, bahkan dalam tataran tertentu menghasilkan \\
dwifungsi tuturan oposisi. Penelitian ini bertujuan untuk mendeskripsikan fungsi tuturan oposisi dan daya pragmatik tuturan oposisi \\
dalam rembuk desa. Sesuai dengan tujuan tersebut, penelitian ini adalah ethno-pragmatics study yang dilaksanakan di sebuah \\
kelurahan di kota Malang, Jawa Timur, Indonesia. Dihadiri oleh kurang lebih 30 orang warga pada tingkat RW dan 50 perwakilan \\
warga dalam rapat Rencana Pengembangan Desa, rembuk desa ini dilaksanakan selama I20 menit, dan peneliti menjadi partisipan \\
observer sebagai unsur akademisi dengan institusi berlokasi pada kelurahan tersebut. Data yang diperoleh selama observasi \\
didokumentasikan dalam bentuk audiovisual yang ditranskripsikan dan dicatat dalam bentuk fieldnote untuk dianalisis sesuai dengan \\
metode padan dan agih. Untuk melengkapi data, interview dilakukan secara mendalam. Temuan dari penelitian ini adalah adanya \\
dwifungsi tuturan oposisi yang meliputi (I) tindak tutur oposisi menolak sekaligus mengeluh, (2) tindak tutur oposisi menolak \\
sekaligus membentak, (3) tindak tutur oposisi menuntut sekaligus membentak, dan (4) tindak tutur oposisi menuntut sekaligus \\
menyindir. Sementara itu, daya pragmatik yang muncul sebagai akibat munculnya dwifungsi tuturan oposisi meliputi (I) \\
melaksanakan, (2) menyetujui (3) membujuk, (4) menggerutu, (5) menyanggah dan (6) berkonfrontasi. Kedua temuan tersebut \\
menunjukkan bahwa ada pergeseran nilai dalam sosiokultural Jawa. Akan tetapi, pergeseran tersebut masih memperhatikan empan \\
papan dan tidak berlaku sepenuhnya. Pemahaman terhadap pergeseran pola komunikasi masyarakat Jawa beserta pola tindak tutur oposisi ini \\
dapat berimplikasi terhadap upaya meminimalisasi terjadinya konflik dalam tuturan.
\end{tabular}

Kata Kunci Daya pragmatik, Dwifungsi tuturan oposisi, Rembuk desa, Tuturan oposisi

\section{ABSTRACT}

The emmergence of opposition speech act in the discourse of deliberations is inevitable, even in certain context creates dual functions of oppocition speech act. This study aims to describe the dual function of opposition speech act and it's pragmatic force in the village deliberations. In accordancce with these objectives, this research is an ethnopragmatics study conducted in a village in Malang, East Java, Indonesia. Attended by approximately 30 residents at the RW level and 50 community representatives at the Village Development Plan Meeting with 120 menutes for each meeting. The researcher became a participant observer as an academic element. The data obtained during the observation were documented in an audiovisual form wich was transcribed and recorded in the form of fieldnotes to be analyzed according to "padan" and "agih" method. To complete the data, in dept interviews were conducted. The findings of this study are the dual functions of oppositional speech act include (I) oppositional speech act rejecting as well as complaining, (2) oppositional speech act rejecting as well as yelling, (3) oppositional speech act request as well as yelling, and (4) oppositional speech act request as well as satirize. Meanwhile, the pragmatic force as a result of the dual function opposition speech act are (I) implementing, (2) agreeing, (3) cajoling, (4) grumbling, (5) refusing, and (6) confronting. These two findings indicate that there is a shift in values in Javanese socioculture. However, this shift pays attention to the board and does not fully apply. The understanding of Javanese pattern of communication shift along with opposition speech act pattern have implications for minimizing conflict in conversation.

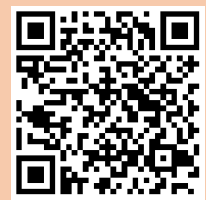

Copyright@202I, Fauzan

This is an open access article under the CC-BY-3.0 license



\begin{tabular}{lll}
\hline \hline Keywords & Pragmatic force, Dual function opposition speech act, Village meetings, Opposition speech act \\
\hline \hline How to Cite & Fauzan, F. (202I). Dwifungsi tuturan oposisi dalam masyarakat bersosiokultur Jawa. KEMBARA: \\
& Jurnal Keilmuan, Bahasa, Sastra dan Pengajarannya (e-Journal), 7(I), I43-I56. doi: \\
& https://doi.org/I0.222I9/kembara.v7iI.I6407 & \\
\hline \hline
\end{tabular}




\section{PENDAHULUAN}

Rembuk desa sebagai sebuah tradisi masyarakat Indonesia (Herutomo, 2019; Santoso, 2013), merupakan sebuah upaya dalam mencapai kesepakatan akan persoalan yang berkaitan desa dalam rangka mewujudkan amanah Undang-Undang Republik Indonesia Nomor 6 tahun 2014 tentang Desa (Dio, 2015; Kushandajani, 2015). Undang-undang tersebut mengatur tentang otonomi dan kewenangan penuh untuk mengelola secara langsung sumber daya manusia dan juga sumber anggaran serta menempati posisi yang sangat strategis dalam tatanan sistem pemerintahan (Hariri, 2019; Herlina et al,, 2017; Simanjuntak, 2015).

Rembuk desa bagi masyarakat Jawa menjadi budaya yang telah dilaksanakan secara turun temurun dan terus menerus karena diyakini sebagai sarana mencapai kesepakatan yang akan diwujudkan bersama. Keunikan rembuk desa di Jawa adalah keragaman latar belakang suku bangsa yang masuk dalam masyarakat tutur Jawa karena alasan bekerja, pendidikan, dan perluasan bisnis. Keragaman inilah yang menyebabkan akulturasi budaya, sehingga sosiokultur Jawa sudah melekat pada warga (Herutomo, 2019; Prasetiyarini, 2014). Proses interaksi dan komunikasi warga dalam kegiatan rembuk desa terlihat dari tindak tutur pesertanya.

Dalam praktik komunikasi tidak selamanya gagasan yang disampaikan oleh penutur memeroleh persetujuan dari lawan tutur (Cooren, 2015). Tidak jarang lawan tutur mengambil sikap berlawanan atau oposisi terhadap tawaran gagasan lawan tutur. Para peneliti menggunakan istilah yang berbeda-beda dalam melabeli kajian yang berkaitan dengan tuturan yang mengandung maksud ketidaksetujuan atau ketidaksepakatan ini. Beberapa istilah yang digunakan oleh para peneliti yang dimaksud (Koczogh, 2013), seperti istilah oposisi (Kakava, 2002), perdebatan/argumen (Budzynska \& Reed, 201 I; Jackson \& Jacobs, 1980; Jacobs, 1989; Walton, 20I4), debat (Johnson \& Johnson, 1985, 2009; Mukherjee \& Liu, 2012; Omelicheva, 2007), konflik (Honda, 2002), perselisihan/pertentangan (Corsaro \& Rizzo, 1990; Goodwin et al., 2002), konfrontasi (Brown, 1990; Hutchby, I993), perbincangan berseberangan (Bardovi-Harlig \& Salsbury, 2004; Corsaro \& Maynard, 1996), dan perbincangan konflik (Grimshaw, 1990; Honda, 2002; Leung, 2005). Perbedaan penggunaan istilah tersebut lebih merupakan selera subjektif peneliti. Hal ini dikarenakan secara substantif istilah-istilah itu memiliki maksud dan semangat yang sama atau hampir sama, yakni tuturan berlawanan (oposisi). Artinya, bermacam-macamnya istilah yang digunakan oleh para ahli tersebut bersumber dari masalah yang sama, yakni adanya tuturan berlawanan (oposisi). Atas dasar itulah penelitian ini menggunakan istilah tuturan oposisi.

Istilah tuturan oposisi dalam praktiknya dapat berupa ketidaksepakatan. Koczogh (2013) mensarikan pendapatnya tentang ketidaksepakatan berkaitan dengan menyampaikan opini atau keyakinan terhadap sebuah pandangan yang bertentangan dengan apa yang diutarakan oleh mitra tutur sebelumnya. Berangkat dari pendapat itu, ada tiga peristiwa yang harus terlibat dalam lahirnya tuturan ketidaksepakatan (oposisi). Pertama, diawali dengan adanya peristiwa atau tuturan yang disampaikan sebelumnya. Kedua, isi pesan yang disampaikan oleh penutur. Isi pesan inilah yang akan menentukan terjadi atau tidaknya tuturan oposisi. Ketiga, responsibilitas dari mitra tutur.

Leech (1983) menyebut tuturan oposisi dengan istilah tuturan bertentangan atau konfliktif. Tuturan bertentangan atau konfliktif diartikan suatu tuturan yang bertentangan dengan tujuan sosial. Tujuan sosial yang dimaksud berkaitan dengan gagasan atau pandangan yang disampaikan penutur untuk memeroleh kesepakatan bersama. Tuturan oposisi dalam praktiknya justru mengandung maksud bertentangan dengan gagasan atau pandangan yang ditawarkan oleh penutur sebelumnya. Menurut Jeffries (20I4) tuturan oposisi dapat dibuat dengan tujuan tertentu, seperti yang pernah dilakukan oleh Obama pada kampanye perebutan posisi Presiden Amerika Serikat. Ia sering kali membuat perbandingan antara penguasa di dunia dengan masyarakat sipil yang tidak memiliki kekuatan secara politik. Obama menciptakan opini publik yang menentang apa kebijakan yang menyebabkan situasi yang tidak menguntungkan bagi rakyat, sehingga dengan menggunakan tindak tutur ilokusi jenis konfliktif. Berdasarkan kajian Rosyidi, Mahyuni, dan Muhaimi (2019), hal serupa juga terjadi pada masa kampanye Joko Widodo pada tahun 2019. 
Praktik tuturan oposisi pada kenyataannya dapat dilakukan dengan berbagai cara. Dalam praktik komunikasi, tuturan oposisi tidak selamanya dikemukakan dengan struktur kalimat negasi yang ditandai dengan hadirnya kata tidak dan sejenisnya seperti dalam kalimat "Saya tidak sependapat", "Saya kurang setuju", dan seterusnya. Akan tetapi, dapat pula dikemukakan dengan struktur kalimat yang "seolah-olah" mendukung gagasan, seperti kalimat "Ya sudah saya sepakat", dan "Kalau memang harus disepakati, ya silakan”. Dua kalimat terakhir itu dapat juga bermaksud oposisi. Prayitno, Ngalim, Rohmadi, dan Riyanto (2018) menyepakati bahwa tuturan oposisi yang disebutkannya sebagai penolakan dapat berupa tuturan yang serta merta disampaikan dengan ungkapan "Tidak.", ataupun "Tunggu dulu.", "Saya capek." Hal demikian, menurut Jeffries (20I4) sangat tergantung pada cara dan konteks tuturan itu digunakan.

Dalam kegiatan rapat, sidang, dan pertemuan-pertemuan lain yang sifatnya memecahkan masalah, adanya tuturan oposisi hampir tidak dapat dihindari. Tuturan oposisi tersebut kadang dapat memicu terjadinya konflik batin dan bahkan fisik. Banyak kejadian adu fisik, seperti memukul, menendang, merusak, dan bahkan saling menyerang fisik yang dipicu oleh adanya tuturan oposisi. Dalam kaitannya dengan munculnya konflik dalam tuturan, Gruber (I998, 200I) menengarai bahwa sebuah percakapan akan mencapai tahap konflik apabila setidaknya terjadi tiga kali perpindahan wicara. Hal itu sebagaimana diilustrasikan berikut ini, (I) A: 'pernyataan'; (20 B: 'pernyataan berlawanan' (tidak setuju terhadap pernyataan A); dan (3) A: 'pernyataan berlawanan dengan pernyataan B' (tidak setuju terhadap pernyataan B).

Dari ilustrasi tersebut dapat dipahami bahwa pernyataan ketiga (pernyataan A yang kedua) menentukan apakah tuturan oposisi akan berujung pada konflik atau tidak. Dengan kata lain, respon terhadap tuturan oposisi itulah yang akan memegang kendali. Apabila tuturan oposisi itu direspon dengan persetujuan, pernyataan yang mengindikasikan pemahaman terhadap tuturan kedua, humor atau respon-respon positif lainnya tentu konflik itu tidak akan terjadi. Begitu sebaliknya, jika pernyataan A yang kedua (sebagaimana contoh di atas) juga berisi tuturan oposisi terhadap pernyataan oposisi B, maka potensi tuturan konflik akan terjadi.

Tindak tutur dalam rapat kedinasan seperti yang telah diteliti oleh Prayitno (2009) menunjukkan dominasi pimpinan rapat dan bersifat direktif namun harus memperhatikan etika kesantunan agar harmoni komunikasi tidak terganggu. Pada situasi yang lain, tindak tutur direktif masih tetap berlaku bagi pemimpin rapat, akan tetapi menggunakan strategi seperti kesantunan positif (positive politeness strategy) dan strategi kesantunan negatif (negative politeness strategy), sehingga rapat dapat terlaksana dengan baik dang menghindari konflik (Mandari et al., 2016). Kedua kasus tersebut berbeda dengan apa yang terjadi pada rembuk desa. Musyawarah desa pada dasarnya merupakan peristiwa negosiasi antara pemegang kekuasaan di tingkat desa dengan peserta musyawarah. Dalam musyawarah desa dilakukan penawaran terhadap suatu hal atau program untuk memeroleh persetujuan peserta musyawarah. Dalam proses untuk mencapai suatu kesepakatan bersama tidak menutup kemungkinan akan adanya tuturan-tuturan oposisi yang digunakan oleh peserta musyawarah.

Negosiasi rembuk desa pada hakikatnya bukan hanya sekedar bertukar tuturan, lebih dari itu para penutur memiliki keterikatan dengan beban latar belakang sosial budaya dan kepentingan yang ada pada dirinya (Makhmudah, 2015; Sigalingging \& Warjio, 20I4). Atas dasar hal itulah tuturan oposisi biasanya akan terjadi. Hal ini sebagaimana yang ditengarai oleh Liliweri (20I4) bahwa konflik dalam organisasi dapat disebabkan oleh adanya perbedaan status dan posisi antara berbagai individu dan kelompok kerja dalam organisasi. Semakin besar perbedaan status dan posisi serta posisi kita terhadap suatu isu, maka makin besar peluang terjadinya konflik organisasi.

Pada dasarnya, penelitian dalam kerangka tindak tutur oposisi telah banyak dilakukan oleh para peneliti terdahulu. Namun, penelitian tersebut lebih mengarah pada kajian tuturan oposisi secara parsial dengan berbagai setting yang dikaitkan dengan kesantunan, seperti tindak tutur mengeluh dalam bahasa Jepang (Winoto \& Aryanto, 2018), tindak tutur menolak dalam budaya Minangkabau (Triana \& Aman, 20I2; Triana, 2016), kesantunan semu dalam tindak tutur marah (Ekawati, 20I7), kesantunan 
kritik dalam masyarakat Jawa (Jauhari, 2018), kesantunan melarang dan mengkritik pada tuju etnis (Halawa, Gani, dan Syahrul, 2019). Di samping itu, dalam kaitannya dengan tindak tutur dan lokus penelitian, penelitian terdahulu lebih banyak membahas tentang tindak tutur secara umum dalam rapat (Santoso, 2013; Mariana \& Konisi, 202I; Suhaima, 2018). Kesemuanya menggunakan kerangka pragmatik, sosiolinguistik, dan/atau sosiopragmatik sebagai pisau analisis.

Merujuk pada uraian penelitian terdahulu tersebut, penelitian ini memiliki kebaruan dalam tiga aspek. Pertama, penelitian ini secara spesifik membahas tentang tindak tutur oposisi yang mengakomodasi beberapa jenis tindak tutur yang mengandung unsur pertentangan. Kedua, penelitian ini dilakukan dalam rembuk desa dengan pisau analisis etnopragmatik. Ketiga, penelitian ini memotret adanya dwifungsi dari tuturan oposisi dalam tuturan yang masih belum dibahas dalam penelitianpenelitian sebelumnya.

Penelitian ini bertujuan untuk menjelaskan (I) bentuk dwifungsi tuturan oposisi dan (2) daya pragmatik tuturan oposisi dalam rembuk desa. Pada akhirnya, kajian terhadap dwifungsi tuturan oposisi dalam rembuk desa ini akan memperluas lanskap kajian pragmatik dalam ranah budaya, utamanya dalam tuturan oposisi, sehingga diperoleh suatu gambaran yang komprehensif terkait pola komunikasi masyarakat dalam kaitannya dengan pemertahanan nilai-nilai budaya Jawa.

\section{METODE}

Penelitian ini adalah penelitian deskriptif kualitatif dalam kerangka etnopragmatik. Penelitian dilakukan di Kelurahan Tlogomas, Kota Malang, Jawa Timur, Indonesia. Data penelitian ini adalah tuturan yang mengandung dwifungsi tuturan oposisi dan daya pragmatik tuturan oposisi yang ditemukan selama rembuk desa berlangsung. Pengambilan data dilakukan melalui observasi partisipan, dengan merekam seluruh kegiatan rembuk desa yang berlangsung selama 120 menit secara audio visual dengan pencatatan data pada field note. Untuk melengkapi data tersebut, in-depth interview dilaksanakan dengan menggunakan daftar pertanyaan yang disusun menjadi semi-struktur interview. Sumber datanya berasal dari peserta rembuk desa.

Rekaman audio visual yang diperoleh selama observasi ditrankripsi dan dikelompokkan secara tematik sesuai bentuk dwifungsi tuturan yaitu tindak tutur oposisi menolak sekaligus mengeluh, tindak tutur oposisi menolak sekaligus membentak, tindak tutur oposisi menuntut sekaligus membentak, dan tindak tutur oposisi menuntut sekaligus menyindir. Dari data tersebut, dikelompokkan pula daya pragmatik tuturan oposisi. Hasil interview juga ditranskripsikan untuk menambah data yang telah diperoleh sebelumnya.

Data yang terkumpul selanjutnya dianalisis menggunakan metode padan dan metode agih. Sejalan dengan itu, teknik yang digunakan adalah teknik lesap, teknik ganti, teknik perluas, teknik sisip, teknik balik, dan teknik ubah wujud. Teknik tersebut digunakan secara bervariasi sesuai dengan karakteristik data.

\section{HASIL DAN PEMBAHASAN}

Dwifungsi tuturan oposisi beserta daya pragmatiknya dalam rembuk desa merupakan cerminan sosiokultural Jawa. Pada dasarnya, nilai budaya Jawa yang utama adalah pemikiran madhang (Endraswara, 2015). Madhang di sini mengacu pada konsep menghilangkan pepeteng urip 'kegelapan hidup'. Dengan kata lain, hidup orang Jawa adalah sebuah perjuangan untuk meraih ketenteraman sejati. Pemikiran tersebut menghasilkan sifat dan karakter masyarakat bersosiokultural Jawa yang menjunjung tinggi harmoni sosial (Susetyo et al., 20I4).

Merujuk pada gagasan di atas, maka masyarakat Jawa diharapkan untuk bersikap, berperilaku, dan bertutur yang tidak berujung pada konflik (Sartini, 2009). Akan tetapi, komunikasi yang berlangsung dalam rembuk desa tidak selalu sejalan dengan harapan para pesertanya yang pada akhirnya menimbulkan hadirnya tuturan oposisi. Apabila kadar emosi tinggi, tak jarang penutur menghasilkan tuturan yang mengandung dwifungsi tuturan oposisi. Dalam hal ini, hasil analisis data menunjukkan bahwa terdapat empat bentuk 
dwifungsi tuturan oposisi yaitu (I) tindak tutur oposisi menolak sekaligus mengeluh, (2) tindak tutur oposisi menolak sekaligus membentak, (3) tindak tutur oposisi menuntut sekaligus membentak, dan (3) tindak tutur oposisi menuntut sekaligus menyindir. Tindak tutur oposisi ini kemudian menimbulkan daya pragmatik bagi mitra tuturnya, yaitu (I) melaksanakan, (2) menyetujui (3) membujuk, (4) menggerutu, (5) menyanggah dan (6) berkonfrontasi. Kedua aspek tersebut selanjutnya secara rinci diuraikan sebagai berikut.

\section{Bentuk Dwifungsi Tuturan Oposisi dalam Rembuk Desa Tindak Tutur Oposisi Menolak Sekaligus Mengeluh}

Tindak tutur oposisi menolak sekaligus mengeluh dilakukan peserta rembuk untuk mengekspresikan ketidaksepakatan terhadap gagasan atau tawaran mitra tutur. Keluhan ini bertolak dari adanya kerugian yang dialami penutur secara langsung (Chen et al., 20II). Tuturan ini dapat disampaikan secara langsung di dalam forum rembuk (on record) maupun di balik forum (off record). Hal itu dikarenakan tindak tutur mengeluh adalah hal yang sulit untuk disampaikan karena dapat mengancam muka positif penutur maupun muka negatif mitra tutur (Yang \& Wannaruk, 2019). Hal ini dapat dilihat pada sajian data berikut.

Dalam rapat PKK, ketua Pokja 2 memaparkan program-programnya. Salah satunya adalah menyelenggarakan kembali lomba senam sehat pada bulan Agustus. Dalam diskusi tersebut, Bu Lurah menyampaikan bahwa kostum perlu dinilai. Beberapa peserta rapat tampak tidak setuju dengan ide itu.

Bu Lurah : Menurut saya kostum penting ya. Sepertinya itu yang bikin rame. Ibu-ibu nanti bisa sangat kreatif dan mungkin lebih semangat.

Peserta : Cckk... Nggawe kreasi kostum barang, ngetokne duwit maneh iki. 'Pakai kostum segala, mengeluarkan uang lagi ini'

Data (I) dituturkan oleh peserta (LS, ibu rumah tangga, 55 tahun) dalam rapat PKK. Tuturan ini disampaikan sebagai respon tuturan (Bu Lurah, 35 tahun) yang menyatakan bahwa dalam lomba senam kostum adalah hal yang penting karena dapat memicu kreativitas dan semangat peserta lomba. Peserta menyampaikan tuturan tersebut di balik forum kepada peserta rapat di sebelah kirinya (ST, 34 tahun). Peserta menyampaikan tuturannya dengan menggumam sembari menoleh kepada t.

Tuturan n dalam data (I) mengindikasikan bahwa n merasa keberatan dengan ide penilaian kostum dalam lomba senam PKK. Adanya penilaian kostum artinya masing-masing kelompok PKK harus mengeluarkan dana untuk membuat kostum baru. Pada tahun sebelumnya, $\mathrm{n}$ harus mengeluarkan dana $\mathrm{Rp}$ I50.000,00 untuk pengadaan kostum. Secara lingual, hal itu dibuktikan dengan tuturan ngetokne duwit maneh iki. Dengan demikian, data (I) merepresentasikan tuturan oposisi menolak sekaligus mengeluh.

Kemunculan tuturan tindak tutur oposisi menolak sekaligus mengeluh ini menunjukkan adanya pergeseran nilai dalam sosiokultur Jawa yang berkecenderungan menghindari konflik. Namun, di sisi lain, bentuk tuturan oposisi menolak sekaligus mengeluh yang disampaikan di balik forum menunjukkan bahwa pergeseran nilai ini tidaklah serta merta. Meski telah berani menunjukkan sikap oposisi, secara umum cara penyampaian tuturan oposisi ini sedapat mungkin masih sejalan dengan pitutur Jawa. Pitutur mengacu pada tuturan yang mengikuti unggah-ungguh basa dan empan papan. Unggah-ungguh basa berkaitan dengan penggunaan ragam bahasa Jawa krama inggil, krama, dan ngoko (Nuryantiningsih \& Pandanwangi, 20I8; Winarti, 2018). Sementara itu, empan papan mengacu pada ungkapan wicaramu kang tata: marang wong gedhe dikumet, marang wong cilik disareh, marang wong sugih diprasaja, marang wong ora duwe (mlarat) diwelas, marang sapadha-padha nganggo duga-duga lan wantara bicaramu yang tertata: kepada orang besar yang santun, kepada orang kecil yang sabar, kepada orang kaya yang lugas, kepada orang miskin yang welas asih, kepada sesama manusia pakai duga-duga dan wantara'. Oleh sebab itu, dengan pertimbangan tersebut, penutur memilih untuk tidak menyampaikan secara langsung keoposisiannya kepada mitra tutur. Hal ini sejalan dengan hasil penelitian Santoso (2013) yang menyatakan bahwa peserta rapat perempuan cenderung menyampaikan tuturan secara tidak langsung. 


\section{Tindak Tutur Oposisi Menolak Sekaligus Membentak}

Tindak tutur oposisi menolak sekaligus membentak dilakukan peserta rembuk untuk menunjukkan ketidaksepakatan terhadap pernyataan, gagasan, atau tawaran mitra tutur. Ketidaksepakatan tersebut tidak hanya direalisasikan dengan pemilihan kata tetapi juga didukung elemen suprasegmental berupa nada tinggi. Dalam hal ini, tindak tutur oposisi menolak sekaligus membentak lazimnya muncul ketika mitra tutur tidak memahami atau mengindahkan tuturan penutur pada beberapa peristiwa tutur sebelumnya. Untuk lebih jelasnya, dapat dicermati data berikut.

Pak RT

Dalam rapat RT 05 RW 03, para peserta rapat mendiskusikan pelaksanaan kegiatan jaga malam. Salah satu pembahasannya adalah nominal denda bagi warga yang tidak melaksanakan piket jaga malam.

SPL Gimana kalau empat puluh ribu? Itu tengah-tengah saya pikir.

\section{: SLAWE EWUAE, PAK!'Dua puluh lima ribu saja, Pak!'}

Data (2) di atas dituturkan oleh SPL (tukang bangunan, 45 tahun) kepada Pak RT dan pemimpin rapat. Tuturan ini merupakan respon atas diskusi panjang nominal denda bagi warga yang tidak jaga malam. Pembahasan diskusi ini selalu mengarah pada angka di atas tiga puluh ribu yang dirasa berat oleh SPL. Pada tuturan sebelumnya, salah seorang peserta juga mengusulkan besaran denda $R p$ 40.000,00. Tuturan disampaikan dengan nada tinggi karena SPL berkali-kali mengacungkan tangan untuk meminta gilir wicara tetapi belum diakomodir. Dengan demikian, data (2) merupakan tuturan oposisi menolak sekaligus membentak.

Bentuk dwifungsi tuturan oposisi menolak sekaligus membentak ini lazimnya hanya dilakukan oleh penutur dengan status sosial lebih tinggi daripada mitra tutur. Hal ini menunjukkan bahwa para penutur bersosiokultur Jawa masih memegang prinsip empan papan. Di samping itu, sebagaimana ditunjukkan oleh data, tuturan semacam ini lazimnya disampaikan oleh laki-laki. Hal ini sejalan dengan hasil penelitian Triana (2016) yang menyatakan bahwa laki-laki lebih cenderung menggunakan strategi langsung dengan berterus terang karena dominasi sifat berani yang dimilikinya.

\section{Tindak Tutur Oposisi Menuntut Sekaligus Membentak}

Tindak tutur oposisi menuntut sekaligus membentak merupakan tindak tutur oposisi yang menyatakan maksud penutur mengharapkan tindakan dari mitra tutur yang disampaikan dengan nada tinggi. Senada dengan tindak tutur menolak sekaligus membentak, tindak tutur ini merupakan dampak dari ketidaklancaran komunikasi pada peristiwa tutur sebelumnya. Oleh karena terjadi kegagalan komunikasi, penutur mengalami peningkatan emosi sehingga diksi, struktur, dan cara penyampaian tuturan bermuatan oposisi. Data menuntut sekaligus membentak disajikan sebagai berikut.

[3] Dalam musrenbang, masing-masing RW melaporkan keuangan selama satu tahun. Peserta rembuk berbisik di balik forum tentang ketidaksinkronan laporan keuangan.

PSH : La itu kok dananya minus tapi masih ada saldo? Nggak beres ikul Aku lak wis omong a... 'Itu tidak beres! Saya kan sudah bilang...'

PJT : IKULHO SEK RUNGUKNO SEK!'Ttu tho dengarkan dulu!'

Data di atas dituturkan oleh PTJ (penjahit, 52 tahun) kepada PSH (pedagang, 46 tahun) sebagai respon atas tuturan PSH yang mempertanyakan laporan keuangan yang menurutnya tidak beres padahal paparan Pak RW tentang laporan keuangan belum selesai. Sejak awal paparan Pak RW, PSH memang sudah berkasak-kusuk dengan peserta lain. PJT sudah dua kali mencoba mengajak PSH untuk fokus dan tidak berbicara sendiri. Namun, PSH masih tetap saja berbuat demikian. PSH memang dikenal sebagai pribadi yang grusa-grusu 'terburu-buru, tidak berpikir panjang' dan acapkali mengeluarkan tuduhan-tuduhan yang tidak terbukti kebenarannya. Oleh sebab itu, saat PSH mengajak PJT berbicara tentang ketidaksinkronan dana dengan sedikit bumbu provokasi, PJT bertutur (3) dengan nada tinggi tanpa melihat ke arah PSH yang 
mengisyaratkan kekesalan terhadap PSH. Adanya nada tinggi ini menandai munculnya tuturan oposisi membentak. Dalam pada itu, tuturan iku tho rungukno sek merepresentasikan adanya tuntutan agar PSH mendengarkan terlebih dahulu paparan Pak RW dan tidak berasumsi yang bukan-bukan. Dengan latar pengalaman tersebut dan juga dengan demikian, data (3) merepresentasikan bimodus tuturan oposisi menuntut sekaligus membentak.

Bagi masyarakat Jawa, tuntutan dan bentakan berlawanan dengan prinsip hormat. Orang yang menuntut dan membentak dianggap sebagai orang yang ora ngajeni 'tidak menghormati' mitra tutur. Mitra tutur diposisikan sebagai orang yang tidak dapat diajak berkomunikasi secara baik-baik dan tidak memahami kehendak penutur. Sama halnya dengan tuturan oposisi menolak sekaligus membentak, tindak tutur oposisi menuntut sekaligus membentak ini lazimnya juga hanya dilakukan apabila hubungan pragmatik menurun. Pada hubungan pragmatik menurun, penutur bisa menggunakan strategi terus terang tanpa basa-basi (Halawa, Ghani, Syahrul, 2019).

\section{Tindak Tutur Oposisi Menuntut Sekaligus Menyindir}

Tindak tutur oposisi menuntut sekaligus menyindir merupakan tindak tutur oposisi yang menyatakan maksud penutur mengharapkan tindakan dari mitra tutur. Namun, tuntutan ini tidak disampaikan secara langsung. Strategi penyampaian tuturan secara tidak langsung ini dalam berbagai budaya memang merepresentasikan kesantunan tuturan (Guo, 2012). Dalam hal ini, tuntutan direalisasikan dalam bentuk kritik, celaan, atau ejekan secara samar kepada peserta rembuk yang bukan merupakan sasaran tuturan atau kepada para peserta secara umum. Data menuntut sekaligus menyindir disajikan sebagai berikut.

\section{Ketua $R T$ memberikan arahan dalam rapat $R T$ tentang kedisiplinan warga dalam pelaksanaan jaga malam.}

Ketua RT : ... Nanti gini "Pak, WES AKU GAK JOGO AE WES, MBAYAR WONG AE PENAK" 'Pak, sudah saya tidak perlu jaga, tinggal membayar orang (untuk menggantikan jaga) saja lebih enak'. Apa tujuannya kan gak seperti itu ya? Tujuannya kan guyub, kampungnya ini bisa guyub, jadi kepeduliannya itu ada gitu loh.

Data (4) di atas dituturkan oleh Ketua RT (PS, pedagang, 57 tahun) kepada warga. Tuturan ini merupakan respon atas pembahasan topik besaran denda bagi warga yang tidak jaga malam dan banyaknya warga lebih memilih membayar denda daripada melaksanakan jadwal jaga malam. $\mathrm{n}$ menyampaikan tuturan dengan nada datar sembari melayangkan pandangan kepada para peserta rapat.

Tuturan yang diawali dengan frasa perandaian yakni nanti gini Pak dan disampaikan dengan impersonasi pada dasarnya merupakan sebuah sindiran kepada warga yang lebih memilih membayar orang untuk menggantikan jaga daripada melaksanakan jadwal jaga malam. Selanjutnya, Pak RT bertutur Tujuannya kan guyub, kampungnya ini bisa guyub, jadi kepeduliannya itu ada gitu loh. Bila dilihat dari aspek sintaksis, tuturan tersebut bermodus deklaratif. Namun, bila dikembalikan pada konteksnya, tuturan tersebut pada dasarnya adalah sebuah larangan. Warga diharapkan tidak membayar orang untuk menggantikan jaga mengingat tujuan utama jaga adalah menjaga keharmonisan sosial dan menunjukkan kepedulian sosial. Dengan demikian, data (4) mengandung makna oposisi melarang sekaligus menyindir.

Larangan menuntut sekaligus menyindir di atas pada prinsipnya menggambarkan sudut pandang penutur. Pak RT merasa ada kelemahan program yang bersumber pada sikap mitra tutur. Akan tetapi, agar tidak mempermalukan mitra tutur, Pak RT tidak menunjukkan amarahnya melainkan bertutur dalam bentuk pasemon. Melalui pasemon, Pak RT berharap peserta rembuk desa mengerti maksudnya. Sebagai orang yang sama-sama hidup dan menjadi bagian dari budaya Jawa yang sejak kecil dididik untuk memiliki sifat rumangsa dan isin, Pak RT berharap warga memiliki kepekaan rasa bahwa dirinyalah yang dimaksud dan timbul perasaan malu, sehingga warga dapat mengubah sikapnya dan memenuhi kehendak Pak RT. Tindak komunikasi Pak RT ini merepresentasikan ciri kepemimpinan Jawa dalam asta brata unsur bumi, yakni kemampuan untuk bersabar (Selvarajah et al., 2017). 


\section{Daya Pragmatik Tuturan Oposisi dalam Rembuk Desa}

Daya pragmatik sebuah tuturan secara umum terbagi menjadi dua, sesuai dengan ilokusi tuturan atau tidak sesuai dengan ilokusi tuturan. Kedua jenis daya pragmatik tersebut dalam konteks tuturan oposisi dalam rembuk desa ini terderivasi menjadi enam jenis daya pragmatik yakni (I) melaksanakan, (2) menyetujui, (3) membujuk, (4) menyanggah, (5) menggerutu, dan (6) berkonfrontasi.

\section{Melaksanakan}

Daya pragmatik melaksanakan merujuk pada tindakan penutur memenuhi permintaan mitra tutur. Daya pragmatik jenis ini didominasi oleh tindak tutur menuntut sekaligus membentak. Adapun wujud tindak tutur menuntut dalam hal ini adalah direktif meminta. Berikut datanya.

Ketua sidang : $\quad$ nominalnya? NOMINALNYA JADI BERAPA?

Perwakilan RW 4 : 150, Pak...

Data (5) dituturkan oleh perwakilan RW 4 (KDR, 57 tahun, dosen) kepada ketua sidang Prona (SN, 54 tahun, pengurus LPMK). Tuturan ini merupakan respon tindak tutur menuntut sambil membentak yang disampaikan ketua siding prona. Pada dua pasang tutur sebelumnya, ketua sidang memang sudah meminta perwakilan RW 4 untuk menyebutkan nominal pengajuan dana. Namun, perwakilan RW 4 tidak memberikan jawaban yang diharapkan sehingga ketua sidang menjadi emosional dan bertanya dengan intonasi tinggi. Dalam merespon tuturan tersebut, perwakilan RW 4 menjawab "I50, Pak..." dengan ekspresi wajah yang berubah menjadi tidak ramah.

\section{Menyetujui}

Daya pragmatik menyetujui merepresentasikan linieritas tindak ilokusi dengan perlokusi. Namun demikian, linieritas ini tidak selalu bermakna penutur sepenuhnya sepaham dengan mitra tutur. Menyetujui dapat pula terjadi karena motivasi mereduksi konflik atau strategi mencapai tujuan. Sebagai contoh dapat dilihat dalam data (6) berikut ini.

\begin{tabular}{|c|c|}
\hline$[6]$ & $\begin{array}{l}\text { Dalam rapat } R W 7 \text { yang membahas tentang persiapan kegiatan bersih desa, } \\
\text { para peserta diminta mengajukan usulan tema kegiatan pawai untuk } R W 7 \text {. } \\
\text { Para peserta mengusulkan beberapa tema, termasuk ketua } R T 3 \text {. }\end{array}$ \\
\hline Pak RT 3 & $\begin{array}{l}\text { Gini Pak RW, saya sama RT } 2 \text { sudah sepakat temanya "Adaptasi dari } \\
\text { perubahan iklim". Itu sudah ngetren di seluruh dunia, Pak! Kalau bukan } \\
\text { itu, kami tidak ikut. }\end{array}$ \\
\hline Pak RW & $\begin{array}{l}\text { Nah, monggo... Niku ya ide bagus. Kalau tema perubahan iklim } \\
\text { memang Pak Agus ahlinya. Monggo Pak jika semua setuju tema itu, } \\
\text { langsung Pak Agus nanti bisa membagi subtema masing-masing RT. }\end{array}$ \\
\hline
\end{tabular}

Dalam merespon tindak tutur menuntut sekaligus mengancam Pak RT 3 (6I tahun, insinyur), Pak RW (52 tahun, pebisnis) menggunakan ungkapan "monggo" dan "ide bagus" yang merepresentasikan daya pragmatik menyetujui. Apabila dilihat dari konteksnya, Pak RW menyetujui usulan tema bukan hanya karena usulannya bagus tetapi lebih pada sebagai upaya mencapai tujuan, yakni terlaksananya kegiatan pawai yang melibatkan seluruh RT. Hal itu bisa dilihat dari tuturan "kalau bukan itu, kami tidak ikut" yang disampaikan Pak RT 3. Di samping itu, pada awal pembahasan kegiatan pawai, Pak RT 3 sudah dengan tegas menyampaikan mau terlibat kegiatan pawai yang berujung adanya adu argumen antara Pak RW dan pak RT 3. 
Dengan demikian, menyetujui dalam konteks data (6) juga merefleksikan upaya meminimalisasi konflik dalam rembuk.

\section{Menggerutu}

Dalam kondisi tertentu, penutur memilih untuk merespon tindak tutur oposisi dengan menggerutu. Tindak tutur menggerutu ini lazimnya disampaikan di balik forum dengan sesama peserta rembuk. Hal itu di satu sisi dilakukan penutur untuk menghindari konflik berkepanjangan dan di sisi lain dilakukan penutur untuk mengekspresikan kekecewaan atau ketidakpuasannya. Konflik secara terbuka memang suatu hal yang sangat dihindari orang Jawa (Sartini, 2009). Untuk lebih jelasnya, dapat dilihat data berikut ini.

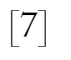

Pak RW 5

Ketua Panitia

Ketua RW 5 : (diam dan mengangguk-angguk) Ya kalo saya pribadi memang nggak setuju sama pawai ini. Biayanya nggak sedikit. Belum lagi macet. Setengah hari lo itu. Dan itu mengganggu pengguna jalan. Belum lagi RW saya itu kan daerah perumahan yang semuanya pekerja. Sulit untuk menyatukan suara. Bikin mereka mau terlibat itu luar biasa sulit.

Dalam merespon tindak tutur oposisi menuntut sekaligus menyindir yang disampaikan ketua panitia (53 tahun, pebisnis), Ketua RW 5 (56 tahun, dosen) hanya diam dan mengangguk-angguk sambil melihat jam tangan yang sudah menunjukkan waktu sore dengan ekspresi tidak puas. Selanjutnya, Ketua RW menyampaikan ketidaksepakatannya terkait pelaksanaan karnaval kepada peserta rembuk di sebelah kirinya. Kehadiran Pak Lurah dalam rembuk agaknya menjadi alasan lain munculnya daya pragmatik menggerutu dibandingkan daya pragmatik lainnya.

Daya pragmatik menggerutu ini membuktikan bahwa masyarakat Jawa masih menunjukkan budaya tidak mau terus terang. Sutarto (2006) menyebutkan bahwa kata inggih 'iya' yang diucapkan oleh orang Jawa belum tentu berarti persetujuan namun bisa jadi merupakan tuturan oposisi - kebalikannya. Bahkan, berbohong juga dilakukan agar mendapatkan penghargaan dari orang lain (Irawanto et al., 20II). Dalam budaya Jawa, kecenderungan bertutur secara semu hakikatnya merupakan sebuah usaha untuk menghindari konflik dan menunjukkan kehalusan budi orang Jawa. Hal itu tertera dalam ungkapan wong Jawa nggone semu, sinamun ing samudana, sesadone adu manis 'Orang Jawa tempatnya semu, tertutup kata-kata tersamar, menghadapi masalah apa pun tetap tersenyum manis' (Sutarto, 2006; Endraswara, 2015). Oleh sebab itu, tidak mengherankan apabila penutur Jawa memiliki karakteristik tidak suka berbicara secara langsung atau tidak suka berterus terang, sehingga dikatakan budaya Jawa adalah budaya simbolis (Sartini, 2009).

\section{Membujuk}

Pada dasarnya, ketidaksetujuan dapat dinegosiasi (Paramasivam, 2007). Dengan kata lain, mitra tutur tidak menerima ketidaksetujuan tersebut dan mencoba memengaruhi mitra tutur untuk berada dalam kesepakatan yang diinginkan. Hal itu dapat terjadi apabila konteks tuturan memungkinkan. Konteks yang dimaksud lazimnya berupa partisipan, baik berupa kehadiran partisipan yang memiliki kedudukan tinggi maupun mitra tutur yang relasi pragmatiknya menaik. Strategi yang digunakan dalam negosiasi ini lazimnya adalah strategi tidak langsung (Pinker, 20I I). Misalnya terlihat pada data (8). 
$[8]$

Bu RW

Ketua Pokja 2 : Ya memang ibu-ibu itu biasanya hari Senin sampai Jumat ada kegiatan. Sabtu mungkin agak longgar tidak mengerjakan apa-apa. Bu Lurah sendiri kan kalau hari Sabtu sudah di rumah. Sudah tidak ada kegiatan ya bu? (menoleh pada Bu Lurah). Ternyata kendala anak datang, tapi sebenarnya nggih saged amargi niki kan nggih mboten dangu senamnya sebenarnya tetap bisa karena senamnya tidak lama'. Atau diajak senam mawon Bu, Mbak Rida. Hehee.

Tuturan “JANGAN HARI SABTU, BU!" pada data (8) menunjukkan bahwa Bu RW (58 tahun, ibu rumah tangga) mengekspresikan ketidaksetujuannya terhadap usulan pelaksanaan senam pada hari Sabtu melalui tuturan oposisi menolak sekaligus membentak. Dalam merespon tindak tutur oposisi tersebut, ketua Pokja 2 mencoba untuk membujuk dengan strategi menyampaikan kembali pernyataan peserta rembuk yang lain, memanfaatkan power partisipan tertinggi (Bu Lurah), dan memberi alternatif solusi. Daya pragmatik membujuk di sini dimungkinkan mengingat mitra tutur berusia lebih tua (hubungan pragmatik menaik) dan antara penutur dan mitra tutur tidak memiliki konflik sebelumnya. Di samping itu, daya pragmatik ini tidak lepas dari faktor gender. Hal ini sejalan dengan hasil penelitian Triana (2016) yang menyatakan bahwa perempuan cenderung menggunakan strategi tidak langsung yang halus dan tidak menyinggung dalam menyampaikan tuturan oposisi.

\section{Berkonfrontasi}

Daya pragmatik berkonfrontasi muncul sebagai upaya penutur untuk mempertahankan gagasannya dalam rembuk. Konfrontasi dimungkinkan apabila penutur memiliki kedudukan sosial yang lebih tinggi daripada mitra tutur. Di samping itu, konfrontasi ini muncul sebagai akibat akumulasi ketidaksepahaman antara penutur dan mitra tutur dalam beberapa peristiwa tutur sebelumnya. Apabila peristiwa tersebut terus berlangsung, maka akan muncul conflict talk (Koczogh, 2013). Sebagai gambaran, dapat dicermati data (9) berikut ini.

[9]

Pak RW
Ketua RT 3
Pak RW
Ketua RT 3

Ketua RT 3
Dalam rapat $R W 7$ yang membahas tentang persiapan kegiatan bersih desa, para peserta diminta mengajukan usulan tema kegiatan pawai untuk $R W$ 7. Pak $R W$ tampak menyetujui usulan tema kerajaan dari RT I dan meminta Ketua RT 3 untuk mensupport kostum.

Pak Agus kalau kerajaan kan punya alatnya.

Dipinjem pusat. Wis rusak!

KAN BISA DIPERBAIKI...

ALAHmalah lebih mahal memperbaiki!!!

Penutur dan mitra tutur dalam data (9) berada dalam kondisi emosi. Pada awal pembahasan karnaval, Pak RT 3 (6I tahun, insinyur) secara lugas menyampaikan tidak akan terlibat dalam kegiatan karnaval. Hal itu menimbulkan ketidaknyamanan bagi Pak RW Pak RW (52 tahun, pebisnis). Mengingat Pak RT 3 lebih senior dan merupakan salah satu sesepuh yang berpengaruh berkat inovasi-inovasinya di bidang lingkungan, Pak RW mencoba membujuk Pak RT 3. Dalam kesempatan perbedaan pendapat berikutnya, Pak RW juga masih menetralisir dengan tindak mbombong. Namun, perbedaan pendapat yang terus berlanjut pada akhirnya menyulut emosi Pak RW, sehingga daya pragmatik yang hadir dalam data (9) adalah berkonfrontasi. Hal itu terlihat dari penggunaan diksi dan nada tinggi dengan ekspresi sinis yang digunakan keduanya sebagai upaya mempertahankan posisinya. Konflik yang demikian pada dasarnya berseberangan dengan nilai-nilai kultural 
Jawa yang memegang teguh prinsip harmoni (Irawanto et al., 20I I; Supriyadi et al., 20I2; Sutarto, 2006). Dengan demikian, dapat dikatakan bahwa masyarakat bersosiokultural Jawa telah mengalami pergeseran nilai (Prayitno, 2009; Wahyuningsi, 2018).

Kenyataan di atas menunjukkan bahwa secara sosiokultural, masyarakat Jawa berada dalam dua tapal. Di satu sisi, masyarakat Jawa mulai meninggalkan nilai-nilai yang tidak lagi dianggap relevan. Nilai-nilai tersebut seperti penurut (manut), tidak suka membantah, pasrah (suwargo nunut neraka katut), dan sejenisnya (Susetyo et al., 20I4). Namun, di sisi lain, masyarakat Jawa masih memegang teguh nilai-nilai kehidupan damai seperti aja dumeh (Supardjo, 2018), tepa selira (Budiyono \& Feriandi, 2017), urip rukun (Setiyadi \& Herawati, 2019), dan sejenisnya sehingga cara penyampaian dan cara merespon dwifungsi tuturan oposisi sedapat mungkin disampaikan secara tidak langsung.

\section{SIMPULAN}

Hasil penelitian menunjukkan bahwa kegiatan rembuk desa di Kelurahan Tlogomas memicu munculnya tindak tutur oposisi. Apabila kadar emosi penutur tinggi, tindak tutur tersebut memuat dwifungsi oposisi. Bentuk dwifungsi tuturan oposisi ini meliputi (I) tindak tutur oposisi menolak sekaligus mengeluh, (2) tindak tutur oposisi menolak sekaligus membentak, (3) tindak tutur oposisi menuntut sekaligus membentak, dan (4) tindak tutur oposisi menuntut sekaligus menyindir. Keempat bentuk dwifungsi tuturan oposisi tersebut memunculkan daya pragmatik (I) melaksanakan, (2) menyetujui, (3) membujuk, (4) menggerutu, (5) menyanggah dan (6) berkonfrontasi. Bertolak dari fakta tersebut, maka dapat dikatakan bahwa ada pergeseran nilai dalam sosiokultural Jawa. Namun, pergeseran tersebut masih memperhatikan empan papan dan tidak berlaku sepenuhnya. Pemahaman terhadap pergeseran pola komunikasi masyarakat Jawa beserta pola tindak tutur oposisi ini dapat berimplikasi terhadap upaya meminimalisasi terjadinya konflik dalam tuturan.

\section{DAFTAR PUSTAKA}

Bardovi-Harlig, K., \& Salsbury, T. (2004). The organization of turns in the disagreements of L2 learners: A longitudinal perspective. In D. Boxer \& A. Cohen (Eds.), Studying speaking to inform second language learning (pp. 199-227). Multilingual Matters.

Brown, P. (1990). Gender, politeness, and confrontation in Tenejapa. Discourse Processes, I3(I), I23-I4I. https://doi.org/I0.1080/01638539009544749

Budiyono, \& Feriandi, Y. A. (2017). Menggali nilai nilai kearifan lokal budaya Jawa sebagai sumber pendidikan karakter. Prosiding Seminar Nasional Bimbingan dan Konseling, I(I), 92-I03. http://prosiding.unipma.ac.id/index.php/SNBK/article/view/II6

Budzynska, K., \& Reed, C. (20II). Speech acts of argumentation: Inference anchors and peripheral cues in dialogue. AAAI Workshop - Technical Report, WS-I I-I0, 3-IO.

Chen, Y. S., Chen, C. Y. D., \& Chang, M. H. (20II). American and Chinese complaints: Strategy use from a cross-cultural perspective. Intercultural Pragmatics, 8(2), 253-275. https://doi.org/IO.I5I5/IPRG.20I1.012

Cooren, F. (2015). Speech act theory: A critical overview. In The international encyclopedia of language and social interaction (pp. I-16). Wiley-Blackwell. https://doi.org/I0.I002/978III86II463/wbielsi055

Corsaro, W. A., \& Rizzo, T. A. (1990). Disputes in the peer culture of American and Italian nursery-school children. In Conflict talk. Sociolinguistic investigations of arguments in conversations (Issue February, pp. 2I-66). Cambridge University Press.

Corsaro, William A, \& Maynard, D. W. (1996). Format tying in discussion and argumentation among Italian and American children. In D. I. Slobin, J. Gerhardt, A. Kyratzis, \& J. Guo (Eds.), Social interaction, social context, and language: Essays in honor of Susan Ervin-Tripp. (pp. I57-174). Lawrence Erlbaum Associates, Inc.

Cummings, J., Butler, B., \& Kraut, R. (2002). The quality of online social relationships: Online relationships are less valuable than offline ones. Indeed their net benefit depends on wether they supplement of 
substitute offline social relationships. Communications of the Amc, 45(7), I03-I08. https://doi.org/IO.I I45/5I4236.5I4242

Dio, Z. R. F. (2015). Kajian yuridis partisipasi masyarakat dalam Undang- undang nomor 6 tahun 2014 tentang desa Hukum Universitas Brawijaya]. https://doi.org/I0.I0I7/CBO978I107415324.004

Eemeren, F. H. Van, \& Grootendorst, R. (1984). Speech acts in argumentative discussions: A theoretical model for the analysis of discussions directed toward solving conflict of opinion. Foris Publication.

Ekawati, M. (2017). Kesantunan semu pada tindak tutur ekspresif marah dalam bahasa Indonesia. Adabiyyāt: Jurnal Bahasa dan Sastra, I(I), I-22. https://doi.org/IO.I442I/ajbs.2017.0IIOI

Endraswara, S. (2015). Etnologi Jawa: Penelitian, perbandingan, dan pemaknaan budaya. Centre for Academic Publishing Service.

Goodwin, C., Goodwin, M. H., \& Olsher, D. (2002). Producing sense with nonsense syllables: Turn and sequence in conversations with a man with severe aphasia. In B. Fox, C. Ford, \& S. Thompson (Eds.), The Language of Turn and Sequence (Issue September 20I4, pp. 56-80). Oxford University Press.

Grimshaw, J. (1990). Argument structure (Linguistic inquiry monographs). In Book I8. The MIT Press. https://doi.org/I0.1017/9780511982378.009

Gruber, H. (1998). Disagreeing: Sequential placement and internal structure of disagreements in conflict episodes. Text, I8(4), 467-503. https://doi.org/I0.I5I5/text.I.I998.I8.4.467

Gruber, H. (200I). Questions and strategic orientation in verbal conflict sequences. Journal of Pragmatics, 33(I2), I8I5-1857. https://doi.org/I0.1016/S0378-2I66(00)00083-7

Guo, Y. (2012). Chinese and American refusal strategy: A cross-cultural approach. Theory and Practice in Language Studies, 2(2), 247-256. https://doi.org/I0.4304/tp1s.2.2.247-256

Halawa, N., Gani, E., \& Syahrul, R. (2019). Kesantunan berbahasa Indonesia dalam tindak tutur melarang dan mengkritik pada tujuh etni. Lingua, 15(2), 195-205. Retrived from https://journal.unnes.ac.id/nju/index.php/lingua/article/view/I7738/95I I

Hariri, A. (2019). Eksistensi pemerintahan desa ditinjau dari perspektif asas subsidiaritas dalam UndangUndang Nomor 6 tahun 2014 tentang desa. Legality: Jurnal Ilmiah Hukum, 26(2), 253. https://doi.org/I0.22219/jihl.v26i2.7799

Herlina, H., Nahar, M. Y., \& Surahman, S. (20I7). Eksistensi otonomi pemerintahan desa berdasarkan Undang-Undang Negara Republik Indonesia Nomor 6 tahun 2014 tentang desa. Jurnal Katalogis, 5(5), III-I2I.

Herutomo, C. (2019). Kearifan lokal lingkungan komunikasi rembug desa dalam menjaga kelestarian hutan di Kesatuan Pemangkuan Hutan (KPH) Banyumas Timur. Journal Acta Diurna, I5(2), 52-63. https://doi.org/I0.20884/I.actadiuma.2019.15.2.2I32

Honda, A. (2002). Conflict management in Japanese public affairs talk shows. Journal of Pragmatics, 34(5), 573-608. https://doi.org/I0.1016/S0378-2I66(0I)00053-4

Hutchby, I. (1993). Confrontation talk: Aspects of 'interruption' in argument sequences on talk radio. Text \& Talk, I2(3), 343-37I. https:// doi.org/I0.1515/text.I.I992.I2.3.343

Irawanto, D. W., Ramsey, P. L., \& Ryan, J. C. (20II). Challenge of leading in Javanese culture. Asian Ethnicity, I2(2), I25-I39. https:// doi.org/I0.I080/I463I369.20I I.57I829

Jackson, S., \& Jacobs, S. (1980). Structure of conversational argument: Pragmatic bases for the enthymeme. Quarterly Journal of Speech, 66(3), 25I-265. https://doi.org/IO.I080/00335638009383524

Jacobs, S. (1989). Speech acts and arguments. Argumentation, 3(4), 345-365. https://doi.org/I0.1007/BF00182603

Jauhari, E. (2018). Alat-alat Kesantunan Kritik dalam Masyarakat Jawa Surabaya: Kajian Pragmatik. Mozaik Humaniora, I8(2), I67-I77.

Jeffries, L. (20I4). Opposition in Discourse: The Constructio of Oppostional Meaning. Bloomsbury. 
Johnson, D. W., \& Johnson, R. (1985). Classroom conflict: Controversy versus debate in learning groups. American Educational Research Journal, 22(2), 237-256. https://doi.org/I0.3I02/000283I2022002237

Johnson, D. W., \& Johnson, R. T. (2009). Energizing learning: The instructional power of conflict. Educational Researcher, 38(I), 37-5I. https://doi.org/I0.3102/00I3I89X08330540

Kakava, C. (2002). Opposition in modern green discourse: Cultural and contextual constraints. Journal of Pragmatics, 34(IO-I I), I537-I568. https:/ / doi.org/I0.I0I6/S0378-2I66(02)00075-9

Koczogh, H. (2013). Scrutinizing the Concept of. 9, 2 I I-222.

Kushandajani, K. (2015). Implikasi UU nomor 6 tahun 2014 tentang desa terhadap kewenangan desa. Yustisia Jurnal Hukum, 4(2), 369-396. https:/ / doi.org/I0.2096I/yustisia.v92i0.3820

Leech, G. N. (1983). Principles of Pragmatics. Longman. https:/ / doi.org/I0.1007/978-3-642-74564-5_I2

Leung, C. (2005). Convivial communication: Recontextualizing communicative competence. International Journal of Applied Linguistics, I5(2), II9-I44. https://doi.org/IO.IIII/j.I4734I92.2005.00084.x

Liliweri, A. (20I4). Sosiologi dan komunikasi organisasi. Yogyakarta: Bumi Aksara.

Makhmudah, K. (2015). Pencegahan konflik melalui local wisdom (Studi model conflict prevention di Desa Sale Kecamatan Sale Kabupaten Rembang). Fakultas Ushuluddin dan Humaniora, Universitas Islam Negeri Walisongo.

Mandari, E., Charlina, \& Mustafa, M. N. (2016). Strategi kesantunan tindak tutur direktif pada rapat BEM FKIP Universitas Riau. Jurnal Online Mahasiswa Fakultas Keguruan dan Ilmu Pendidikan Universitas Riau, Oktober, I-8.

Mariana, M., \& Konisi, L. Y. Tindak tutur dalam rapat organisasi hippma oempu di Kota Kendari (tinjauan pragmatik). Jurnal Bastra (Bahasa dan Sastra), 6(I), 94-I08. http://dx.doi.org/I0.36709/jb.v6iI.I63I3

Mukherjee, A., \& Liu, B. (2012). Analysis of linguistic style accommodation in online debates. 24th International Conference on Computational Linguistics - Proceedings of COLING 20I2: Technical Papers, December 2012, I83I-I846.

Nuryantiningsih, F., \& Pandanwangi, W. D. (2018). Politeness and Impoliteness in Javanese Speech Levels. Proceedings of the Fourth Prasasti International Seminar on Linguistics (Prasasti 2018), I66(Prasasti), 383-387. https://doi.org/I0.2991/prasasti-18.2018.70

Omelicheva, M. Y. (2007). Resolved: Academic debate should be a part of political science curricula. Journal of Political Science Education, 3(2), I6I-I75. https://doi.org/IO.I080/I55I2I6070I338320

Paramasivam, S. (2007). Managing disagreement while managing not to disagree: Polite disagreement in negotiation discourse. Journal of Intercultural Communication Research, 36(2), 9I-II6. https://doi.org/I0.I080/I747575070I47866I

Pinker, S. (20II). Indirect speech, politeness, deniability, and relationship negotiation: Comment on Marina Terkourafi's "The Puzzle of Indirect Speech." Journal of Pragmatics, 43(II), 2866-2868. https://doi.org/I0.I0I6/j.pragma.201 1.05.005

Prasetiyarini, R. (2014). Pelanggaran prinsip kesopanan dalam rembuk desa di Kelurahan Jatiroto Kabupaten Wonogiri [Universitas Muhmmadiyah Surakarta]. https://doi.org/I0.I530/EJE-I4-0355

Prayitno, H. J., Ngalim, A., Rohmadi, M., \& Riyanto, U. (2018). Strategies of refusal speech act by Javanese culture-based students at Darul Ihsan Muhammadiyah Islamic Boarding School Sragen. Journal of Education and Learning (EduLearn), I2(3), 520. https:// doi.org/I0.I I59I/edulearn.vI2i3.9300

Prayitno, J. H. (2009). Perilaku tindak tutur berbahasa pemimpin dalam wacana rapat dinas: Kajian Pragmatik Dengan Pendekatan Jender. Kajian Linguistik Sastra, 2I(2), I32-I46.

Rosyidi, A. Z., Mahyuni, \& Muhaimi. (2019). Illocutionary speech acts use by Joko Widodo in first Indonesia Presidential election debate 2019. International Journal of Multicultural and Multireligious Understanding, 6(2), 735-740. 
Santoso, H. D. (2013). Apitan: Pelestarian tradisi agraris lokal masyarakat Jawa. Lensa: Kajian Kebahasaan, Kesusastraan, dan Budaya, 3(2), 77-85.

Sartini, N. W. (2009). Menggali nilai kearifan lokal budaya Jawa lewat ungkapan (bebasan, saloka, dan paribasa). Jurnal Logat, 5(I), 28-37.

Schiffrin, D. (1994). Approaches to discourse: Blackwell textbooks in linguistics. Blackwell Publishing Ltd.

Selvarajah, C., Meyer, D., Roostika, R., \& Sukunesan, S. (2017). Exploring managerial leadership in Javanese (Indonesia) organisations: engaging Asta Brata, the eight principles of Javanese statesmanship. Asia Pacific Business Review, 23(3), 373-395. https:/ / doi.org/I0.1080/I3602381.2016.I2I3494

Setiyadi, D. B. P., \& Herawati, N. (2019). Values of character education in the Javanese local wisdom. 7(2), 939-946. https://doi.org/I0.248I5/.vIiI.I4866

Sigalingging, A. H., \& Warjio. (20I4). Partisipasi masyarakat dalam perencanaan pembangunan (Studi kasus pada Kecamatan Sidikalang Kabupaten Dairi). Jumal Administrasi Publik, 2(2), II6-I45.

Simanjuntak, K. (2015). Implementasi kebijakan desentralisasi pemerintahan di Indonesia. Jurnal Bina Praja, 7(2), II I-I30. https://doi.org/I0.2I787/jbp.07.20I5.II I-I30

Söderlind, J. (1964). Utterance, sentence, and clause as English speech-units. English Studies, 45(I-6), 50-56. https://doi.org/I0.I080/00I38386408597186

Suhaima, S. (2018). Tindak tutur anggota dewan dalam rapat formal di kantor DPRD Medan (Doctoral dissertation, UNIMED).

Supardjo. (2018). Javanese discussion values in the noble event of forming personality. 280(Basa), 544-547.

Supriyadi, B., Sudarwanto, B., \& Werdiningsih, H. (20I2). In search of the power of Javanese culture against the cultural urbanization in Kotagede, Yogyakarta-Indonesia. Procedia - Social and Behavioral Sciences, 68, 676-686. https://doi.org/I0.I0I6/j.sbspro.20I2.12.258

Susetyo, D. B., Widiyatmadi, H. E., \& Sudiantara, Y. (20I4). Konsep self dan penghayatan self orang Jawa. Psikodimensia, I3(I), 47. https://doi.org/I0.24I67/psiko.vI3iI.277

Sutarto, A. (2006). Becoming a true Javanese: A Javanese view of attempts at Javanisation. Indonesia and the Malay World, 34(98), 39-53. https:/ / doi.org/I0.I080/I3639810600650893

Triana, H. W., \& Aman, I. (20II). Lakuan tutur menolak generasi muda Minangkabau: cermin budaya popular dalam interaksi sosial. Gema Online $\mathbb{B}$ Journal of Language Studies, I2(I), I7-34. Retrved from https:// ejournal.ukm.my/gema/article/view/64

Triana, H. W. (2016). Fenomena gender dalam perilaku tutur menolak etnik Minangkabau modern. Kafaah: Journal of Gender Studies, 6(2), 215-234. http://dx.doi.org/I0.I5548/jk.v6i2.I46

Wahyuningsi, E. (2018). Pergeseran nilai budaya Jawa dalam novel Canting karya Arswendo Atmowiloto: Suatu kajian antropologi sastra. Jurnal KATA, 2(2), 326. https://doi.org/I0.222I6/jk.v2i2.36I8

Walton, D. (20I4). Speech acts and indirect threats in ad baculum arguments: A reply to Budzynska and Witek. Argumentation, 28(3), 3I7-324. https://doi.org/I0.I007/sI0503-0I4-93I8-2

Winarti, O. (2018). Language shift of krama to bahasa Indonesia among Javanese youths and it's relation to parents' social class. Jurnal Studi Komunikasi (Indonesian Journal of Communications Studies), 2(3), 290. https://doi.org/I0.25I39/jsk.v2i3.186

Winoto, D. R., \& Aryanto, B. (2018). Tindak Tutur Mengeluh Bahasa Jepang: Studi Kasus dalam Film Great Teacher Onizuka (20I2). LITE: Jurnal Bahasa, Sastra, dan Budaya, I4(I), II-24. https://doi.org/I0.33633/lite.vI4iI.I975

Yang, L., \& Wannaruk, A. (2019). A cross-cultural pragmatic study of the speech act of complaining by native thai and chinese speakers. Kasetsart Journal of Social Sciences, 40(3), 670-676. https://doi.org/I0.I0I6/j.kjss.2018.06.004 